\title{
Marine social science for the peopled seas ${ }^{1}$
}

Journal: Coastal Management

Author: Nathan J. Bennett ${ }^{1,2,3}$

\begin{abstract}
Affiliations:
${ }^{1}$ Institute for the Oceans and Fisheries \& Institute for Resources, Environment and Sustainability, University of British Columbia, Canada

${ }^{2}$ University of Nice Sophia Antipolis, France

${ }^{3}$ Center for Ocean Solutions, Stanford University, USA
\end{abstract}

\begin{abstract}
Coastal communities, indigenous peoples, and small-scale fishers rely on the ocean for livelihoods, for subsistence, for wellbeing and for cultural continuity. Thus, understanding the human dimensions of the world's peopled seas and coasts is fundamental to evidence-based decision-making across marine policy realms. This perspective paper contends that the marine social sciences must inform the pursuit of sustainable oceans. To this end, the paper introduces this burgeoning field and reviews the insights that social science can offer to guide ocean and coastal policy and management. The upcoming United Nations Decade of Ocean Science for Sustainable Development (2021-2030) provides a tremendous opportunity to build on the current interest, need for and momentum in the marine social sciences. We will be missing the boat if the marine social sciences do not form an integral and substantial part of the mandate and investments of this global ocean science for sustainability initiative.
\end{abstract}

Keywords: marine social science, human dimensions, sustainability science, ocean governance, marine policy, UN Decade of Ocean Science

\section{People and the sea}

The importance of the ocean to humans cannot be overstated. The oceans produce essential food and sustenance, provide other raw materials (e.g., medicine, minerals) and non-material benefits (e.g., recreation, tourism), and regulate climatic, atmospheric, material and energy cycles. Globally, marine capture fisheries and aquaculture produced more than 79.3 and 28.7 million tons of fish - providing an estimated 59.6 million jobs worldwide and 17\% of all animal protein consumed globally (FAO, 2018). The economic value of the overall contribution of the ocean's ecosystem services to human well-being has been estimated at USD21 trillion per year, which represents $\sim 60 \%$ of the economic value of the biosphere (Costanza, 1999). These statistics portray the momentous importance of the ocean for society, while neglecting the obvious: we simply cannot live without the ocean.

High-level facts and narratives such as these can also gloss over the myriad ways that coastal populations who live on or near the ocean depend directly on and value the marine environment. Coastal communities, indigenous people and small-scale fishers rely on the oceans for livelihoods, for food security, for wellbeing and for cultural continuity. The UN estimates there are more than 600 million people $(\sim 10 \%)$ living in coastal areas and up to 2.4 billion people $(\sim 40 \%)$ living within $100 \mathrm{~km}$ of the shore (United Nations, 2017). Many people in coastal communities depend on the ocean for their livelihoods - with an estimated 12-14 million small-scale fishers globally and a further 38 million working in post-harvest jobs (Jacquet \& Pauly, 2008; The World Bank, 2005). Coastal populations also rely on fishing and harvesting for food security - with indigenous groups and small-island states

${ }^{1}$ This is a pre-print version of an article that can be cited as follows: Bennett, N. J. (2019). Marine social science for the peopled seas. Coastal Management. https://doi.org/10.1080/08920753.2019.1564958 
consuming a much higher level of fish than the general populace (Cisneros-Montemayor, Pauly, Weatherdon, \& Ota, 2016; FAO, 2018). Connections to the sea go much deeper than economic value, jobs or food security as coastal societies have deep historical roots and cultural connections to the ocean which cannot be quantified or replaced (Poe, Norman, \& Levin, 2014).

Moreover, while the marine area within 200 nautical miles from the coast is within the Exclusive Economic Zones of nation states under the United Nations Convention on the Law of the Sea (UNCLOS), the coastal margin might be more accurately described as the domain of indigenous peoples, small-scale fishers, and coastal communities. Much of the world's oceans and coasts are peopled seascapes. Decisions made and actions taken in the marine and coastal environment can have profound impacts on these people who depend on the sea for livelihoods, for sustenance, for wellbeing and for cultural survival. Future ocean science efforts aiming to promote sustainability would thus benefit from taking the human dimensions into account. With a broad mandate to "gather ocean stakeholders worldwide behind a common framework that will ensure ocean science can fully support countries in creating improved conditions for sustainable development of the ocean", the UN Decade of Ocean Science for Sustainable Development (2021-2030) is one such effort that must include adequate attention to and investments in the marine social sciences.

\section{Oceans of opportunity and activity}

Recent decades have seen significant growth in attention to the oceans - as a space with potential for growth in development activities and, simultaneously, as a site that needs to be managed and conserved. While many fisheries within territorial waters may already be fished beyond sustainable levels, the global spatial and ecological footprint of fisheries has continued to expand (Swartz, Sala, Tracey, Watson, \& Pauly, 2010) and island states and developing nations often see fisheries as an area of growth (Michel, 2017). Development of the broader "blue economy" - including aquaculture, marine tourism, renewable energy, oil, and underwater mining - is receiving increased attention from global investment firms, multi-lateral organizations, and small island states alike (Lloyds, 2014; Michel, 2017; World Bank \& United Nations, 2017). This blue growth is producing profound changes in the oceans through the cumulative impacts of human activities on marine species, ecosystems and functioning (Halpern et al., 2008; Nash et al., 2017).

Alongside blue growth, there has been an increase in marine conservation and management efforts. The number and area covered by marine protected areas globally has increased to cover $6.97 \%$ of the ocean (Álvarez-Romero et al., 2018). Fisheries management and rebuilding efforts worldwide have also increased, though there is significant variation in the extent to which this has brought fisheries within sustainable limits (FAO, 2018; Teh et al., 2017). More than 70 countries, or $45 \%$ of coastal states, have marine spatial planning efforts that are currently being developed or implemented (Frazão Santos et al., 2018). Lastly, in 2015, the United Nations finalized the Sustainable Development Goals including an ocean specific goal - Goal 14: Life Below Water - that has targets to reduce pollution and acidification, restore habitats, eliminate overfishing, conserve marine areas, eliminate fishing subsidies, and increase economic benefits to small-island and developing countries.

However, these activities are most-often occurring in seas that are occupied and used by people. Even fishing and genetic resource harvesting activities occurring in the high seas can have disproportionate impacts and benefits for different developing and developed nations (Blasiak et al., 2016; Sumaila et al., 2015). Thus, decisions made and actions taken in different ocean policy realms ought to be guided by an understanding of the human dimensions - including social, cultural, economic, health, and governance considerations - of the marine and coastal environment (Christie et al., 2017). This is true across all marine policy realms - including marine conservation, marine spatial planning, fisheries management, blue economy and climate adaptation - as well as when addressing specific subtopics such as marine pollution, invasive species or marine mammal by-catch. The marine social 
sciences can help fill this requirement for attention to the human dimensions in ocean governance and management.

\section{The marine social sciences}

The marine social sciences draw from a diverse and well-established set of disciplines, methods, and theories to rigorously study the human dimensions of ocean and coastal issues and challenges (Aswani et al., 2017; Bennett et al., 2017). The traditional disciplines, such as anthropology, sociology, economics, geography, political science, history, and psychology, can inform marine social science efforts. So too can more applied disciplines - such as law, education, communication studies, and development studies - and interdisciplinary efforts that examine the marine environment as a socialecological system. Drawing on diverse disciplinary roots, the field employs a broad array of methods including quantitative (e.g., surveys, economic analysis), qualitative (e.g., interviews, focus groups, archival research) and participatory methods (e.g., participatory mapping, community-based research, action research, arts-based methods). Various outputs can be produced - ranging from narrative accounts of the changes occurring in the marine environment or coastal communities, to maps of areas of social or cultural importance, to economic analyses of the costs and benefits of development or management activities, to prioritized lists of preferred policy alternatives. Finally, marine social scientists focus on different social science topics - such as governance and management, human use and impacts, tenure and rights, values and culture, human-well-being and social impacts, equity and justice, social resilience, behavior and livelihoods - to understand and help address concerns related to ocean policy. The following text reviews how research on these topics can provide practical insights for ocean management.

Research on governance can characterize who is involved in decision-making structures or how decisions are made in response to emerging issues in the ocean (Campbell et al., 2016), evaluate the performance or functioning of the governance processes in marine protected areas or fisheries (Jones, 2014; Stephenson et al., 2018), or diagnose the institutional factors that are leading to different social or ecological outcomes (Cinner et al., 2016; Jupiter et al., 2017). Management effectiveness evaluations track the relative status of management inputs, processes, outputs and activities and evaluate their effects on ecological and social outcomes in marine protected areas (Gill et al., 2017; Rodríguez-Rodríguez et al., 2015) or fisheries management (Anderson et al., 2015; Stephenson et al., 2018). These assessments and evaluations can be used to facilitate improvements in ocean governance and management.

The tools of social science can also be used to document human uses, rights and tenure, values, and cultural considerations, which can inform spatial planning and management decisions across marine policy realms. The spatial characterization of different human uses and the nature and magnitude of ecological impacts can be used in structured decision-making or trade-off analyses during marine spatial planning processes (Kittinger et al., 2014). Social science techniques can also be employed to elicit people's values and assign relative value to ecosystem services provided by the marine environment for incorporation into decision-making (Estévez \& Gelcich, 2015; Lopes \& Videira, 2013). The documentation of cultural values, traditional knowledge, customary practices and areas or species of cultural significance can enable the incorporation of cultural considerations into marine conservation planning and management efforts (Gee et al., 2017; Poe et al., 2014). Social scientists can also provide evidence of present use and historical tenure and access of different groups (eg, indigenous peoples, small-scale fishers) for inclusion in MPA and marine spatial planning efforts (Aswani \& Lauer, 2006; Mangubhai et al., 2015).

The marine social sciences can be drawn on to understand the impacts - both costs and benefits of management decisions and development actions for economic wealth, human well-being, or social equity. Economic analysis might be employed to calculate the value of ocean ecosystem services or to understand how the costs and benefits of different management scenarios will be shared among current 
and future generations (Costanza, 1999; Sumaila et al., 2015). These analyses might inform policy deliberations on the most equitable or efficient courses of action in fisheries management, be used to design compensation schemes in marine conservation or inform the configuration of Impact-Benefit Agreements from blue economy developments. Scholarship on human well-being aims to understand the holistic status of groups and communities across social, cultural, financial, health and physical domains (Breslow et al., 2016; Weeratunge et al., 2014). Assessments of human-wellbeing be applied to identify how people benefit from the marine environment, to establish social baselines and track the social impacts of environmental change or marine conservation over time, and to adapt management efforts and improve social outcomes (Kaplan-Hallam \& Bennett, 2018). Social equity studies concentrate on levels of procedural fairness and the distributional impacts of marine conservation, management and development activities (Bennett, 2018; Hanich, Campbell, Bailey, \& Molenaar, 2015).

Finally, the social sciences can help to identify the social and contextual factors that influence the behaviours, actions or responses of individuals or collectives (e.g., organizations, communities) or society. Social vulnerability and resilience scholars, for example, study the social and institutional factors that lead to differential vulnerabilities of individuals or groups (e.g., coastal communities, smallscale fishers, women) to climate change or other environmental hazards, and that shape their capacity to proactively plan for and adapt to change (Cinner et al., 2018; Tuler, Webler, \& Polsky, 2013). A significant body of social science research focuses on the cognitive (e.g., knowledge, perceptions, motivations, norms), social and institutional drivers of collective actions in natural resource management (Jentoft et al., 2018; Ovando et al., 2013), individual behaviours in fisheries (Fulton, Smith, Smith, \& Putten, 2011) or levels of support for conservation (Jefferson et al., 2015; McNeill, Clifton, \& Harvey, 2018). Studies employing the sustainable livelihoods approach examine how different contextual factors, levels of individual capacity and institutions influence the social and ecological outcomes of local marine and coastal livelihood strategies (eg, fisheries, aquaculture, tourism) and the efficacy of alternative livelihood programs (Allison \& Ellis, 2001; Ferrol-Schulte et al., 2013). A solid understanding of the influence of different social and contextual factors can aid in the identification of effective intervention points for community-level or managerial actions to enable local marine stewardship activities, pro-environmental behaviours, environmentally sustainable livelihoods, local support for marine conservation or the adaptive capacity of coastal populations to climate change.

In sum, the marine social sciences can offer important insights to guide ocean and coastal policy and management through: a) characterizing and evaluating the efficacy of governance and management, b) documenting the social context to inform planning and management, c) assessing the impacts of conservation, management or development activities on human well-being, and d) identifying the social and institutional factors that influence people's behaviours, actions or responses.

\section{From social science to evidence-informed ocean policy}

As governments and other organizations around the world increasingly focus on the ocean, it behooves them to make decisions based on the best available evidence - which includes consideration of both biophysical and human dimensions and justifies a need for both natural and social science. Yet, despite the importance and potential contributions of the marine social sciences for understanding the human dimensions of ocean and coastal policy, government agencies, NGOs, funders or multi-lateral agencies rarely have sufficient capacity or make adequate investments in social science. This means that planning and decision-making for many local, national and global ocean-focused policy initiatives ranging from local fisheries management initiatives to national marine conservation efforts to the International Union for the Conservation of Nature's (IUCN) Marine Program - lack sufficient grounding in the social sciences. There are substantial risks to ignoring the social context of sustainability, ranging from unethical actions to backlash against conservation, management or development initiatives (Bennett, 2018; Kelly, Pecl, \& Fleming, 2017). 
Around the world, there are numerous important efforts arising to fulfill the need for greater marine social science in the ocean sustainability agenda. These efforts range from local to global in focus. In the Salish Sea, a transboundary region of the Pacific Ocean spanning the USA and Canada border, a nascent working group is exploring how the social sciences can be applied to ecosystem recovery. Similarly, a fledgling Marine Social Sciences Network was recently launched in the UK to promote the use of social science in coastal and ocean decision-making and management (https://www.marsocsci.net/). Global research initiatives, such as the Integrated Marine Biosphere Research, the International Council for the Exploration of the Sea, the Earth Systems Governance Project and Future Earth projects, all have working groups or clusters that focus on human dimensions, governance, or integrated research on the ocean and coastal environment.

However, marine social science initiatives are still too few and far between, with vast regions and ocean policy realms still largely neglected. A coordinated global effort is needed to build a community of practice and catalyze insights from the marine social sciences to guide marine and coastal policy. For such an effort to be more than peripheral in ocean science and sustainability efforts and to scale up will require attention and investments. The upcoming UN Decade of Ocean Science for Sustainable Development (2021-2030) provides a tremendous opportunity to build on the current interest, need for and momentum in the marine social sciences. We will be missing the boat if the marine social sciences do not form an integral and substantial part of the mandate and investments of this global ocean science for sustainability initiative.

\section{$\underline{\text { References }}$}

Allison, E., \& Ellis, F. (2001). The livelihoods approach and management of small-scale fisheries. Marine Policy, 25(5), 377-388.

Álvarez-Romero, J., Mills, M., Adams, V., Gurney, G., Pressey, R., Weeks, R., ... Storlie, C. (2018). Research advances and gaps in marine planning: towards a global database in systematic conservation planning. Biological Conservation, 227, 369-382.

Anderson, J., Anderson, C., Chu, J., Meredith, J., Asche, F., Sylvia, G., ... Valderrama, D. (2015). The Fishery Performance Indicators: A Management Tool for Triple Bottom Line Outcomes. PLoS ONE, 10(5), e0122809.

Aswani, S., Basurto, X., Ferse, S., Glaser, M., Campbell, L., Cinner, J. , ... Christie, P. (2017). Marine resource management and conservation in the Anthropocene. Environmental Conservation, 111.

Aswani, S., \& Lauer, M. (2006). Incorporating fishermen's local knowledge and behavior into geographical information systems (GIS) for designing marine protected areas in Oceania. Human Organization, 65(1), 81-102.

Bennett, N. (2018). Navigating a just and inclusive path towards sustainable oceans. Marine Policy, 97 , 139-146.

Bennett, N., Roth, R., Klain, S., Chan, K., Christie, P., Clark, D., ... Wyborn, C. (2017). Conservation social science: Understanding and integrating human dimensions to improve conservation. Biological Conservation, 205, 93-108.

Blasiak, R., Pittman, J., Yagi, N., \& Sugino, H. (2016). Negotiating the Use of Biodiversity in Marine Areas beyond National Jurisdiction. Frontiers in Marine Science, 3, 224.

Breslow, S., Sojka, B., Barnea, R., Basurto, X., Carothers, C., Charnley, S., ... Levin, P. (2016). Conceptualizing and operationalizing human wellbeing for ecosystem assessment and management. Environmental Science \& Policy, 66, 250-259. 
Campbell, L., Gray, N., Fairbanks, L., Silver, J., Gruby, R., Dubik, B., \& Basurto, X. (2016). Global Oceans Governance: New and Emerging Issues. Annual Review of Environment and Resources, 41(1), 517-543.

Christie, P., Bennett, N., Gray, N., 'Aulani Wilhelm, T., Lewis, N., Parks, J., ... Friedlander, A. (2017). Why people matter in ocean governance: Incorporating human dimensions into large-scale marine protected areas. Marine Policy, 84, 273-284.

Cinner, J., Adger, W., Allison, E., Barnes, M., Brown, K., Cohen, P., ... Morrison, T. (2018). Building adaptive capacity to climate change in tropical coastal communities. Nature Climate Change, 1.

Cinner, J., Huchery, C., MacNeil, M., Graham, N., McClanahan, T., Maina, J., ... Mouillot, D. (2016). Bright spots among the world's coral reefs. Nature, 535, 416-419.

Cisneros-Montemayor, A., Pauly, D., Weatherdon, L., \& Ota, Y. (2016). A Global Estimate of Seafood Consumption by Coastal Indigenous Peoples. PLOS ONE, 11(12), e0166681.

Costanza, R. (1999). The ecological, economic, and social importance of the oceans. Ecological Economics, 31(2), 199-213.

Estévez, R., \& Gelcich, S. (2015). Participative multi-criteria decision analysis in marine management and conservation: Research progress and the challenge of integrating value judgments and uncertainty. Marine Policy, 61, 1-7.

FAO (2018). The state of world fisheries and aquaculture: Meeting the sustainable development goals. Rome: Food and Agriculture Organization of the United Nations.

Ferrol-Schulte, D., Wolff, M., Ferse, S., \& Glaser, M. (2013). Sustainable Livelihoods Approach in tropical coastal and marine social-ecological systems: A review. Marine Policy, 42, 253-258.

Frazão Santos, C., Agardy, T., Andrade, F., Crowder, L., Ehler, C., \& Orbach, M. (2018). Major challenges in developing marine spatial planning. Marine Policy. Online: https://doi.org/10.1016/j.marpol.2018.08.032

Fulton, E., Smith, A., Smith, D., \& van Putten, I. (2011). Human behaviour: the key source of uncertainty in fisheries management. Fish and Fisheries, 12(1), 2-17.

Gee, K., Kannen, A., Adlam, R., Brooks, C., Chapman, M., Cormier, R., ... Shellock, R. (2017). Identifying culturally significant areas for marine spatial planning. Ocean \& Coastal Management, 136, 139-147.

Gill, D., Mascia, M., Ahmadia, G., Glew, L., Lester, S., Barnes, M., ... Fox, H. (2017). Capacity shortfalls hinder the performance of marine protected areas globally. Nature, 543, 665-669.

Halpern, B., Walbridge, S., Selkoe, K., Kappel, C., Micheli, F., D’Agrosa, C., ... Watson, R. (2008). A global map of human impact on marine ecosystems. Science, 319(5865), 948-952.

Hanich, Q., Campbell, B., Bailey, M., \& Molenaar, E. (2015). Research into fisheries equity and fairness - addressing conservation burden concerns in transboundary fisheries. Marine Policy, 51, 302-304.

Jacquet, J., \& Pauly, D. (2008). Funding Priorities: Big Barriers to Small-Scale Fisheries. Conservation Biology, 22(4), 832-835.

Jefferson, R., McKinley, E., Capstick, S., Fletcher, S., Griffin, H., \& Milanese, M. (2015). Understanding audiences: Making public perceptions research matter to marine conservation. Ocean \& Coastal Management, 115, 61-70.

Jentoft, S., Bavinck, M., Alonso-Población, E., Child, A., Diegues, A., Kalikoski, D., ... Rivera, V. (2018). Working together in small-scale fisheries: harnessing collective action for poverty eradication. Maritime Studies, 1-12.

Jones, P. J. S. (2014). Governing Marine Protected Areas: Resilience Through Diversity. New York, NY: Routledge.

Jupiter, S., Epstein, G., Ban, N., Mangubhai, S., Fox, M., \& Cox, M. (2017). A Social-Ecological Systems Approach to Assessing Conservation and Fisheries Outcomes in Fijian Locally Managed Marine Areas. Society \& Natural Resources, 30(9), 1096-1111. 
Kaplan-Hallam, M., \& Bennett, N. (2018). Adaptive social impact management for conservation and environmental management. Conservation Biology, 32(2), 304-314.

Kelly, R., Pecl, G., \& Fleming, A. (2017). Social licence in the marine sector: A review of understanding and application. Marine Policy, 81, 21-28.

Kittinger, J., Koehn, J., Le Cornu, E., Ban, N., Gopnik, M., Armsby, M., ... Crowder, L. (2014). A practical approach for putting people in ecosystem-based ocean planning. Frontiers in Ecology and the Environment, 12(8), 448-456.

Lloyds. (2014). Global Marine Trends 2030. London, UK: Lloyd's Register Group Limited (LR).

Lopes, R., \& Videira, N. (2013). Valuing marine and coastal ecosystem services: An integrated participatory framework. Ocean \& Coastal Management, 84, 153-162.

Mangubhai, S., Wilson, J., Rumetna, L., Maturbongs, Y., \& Purwanto. (2015). Explicitly incorporating socioeconomic criteria and data into marine protected area zoning. Ocean \& Coastal Management, 116, 523-529.

McNeill, A., Clifton, J., \& Harvey, E. (2018). Attitudes to a marine protected area are associated with perceived social impacts. Marine Policy, 94, 106-118.

Michel, J. A. (2017). Rethinking the Oceans: Towards the Blue Economy. Paragon House.

Nash, K., Cvitanovic, C., Fulton, E., Halpern, B., Milner-Gulland, E., Watson, R., \& Blanchard, J. (2017). Planetary boundaries for a blue planet. Nature Ecology \& Evolution, 1(11), 1625.

Ovando, D., Deacon, R., Lester, S., Costello, C., Van Leuvan, T., McIlwain, K., ... Uchida, H. (2013). Conservation incentives and collective choices in cooperative fisheries. Marine Policy, 37, 132140.

Poe, M., Norman, K., \& Levin, P. (2014). Cultural Dimensions of Socioecological Systems: Key Connections and Guiding Principles for Conservation in Coastal Environments: Cultural dimensions of coastal conservation. Conservation Letters, 7(3), 166-175.

Rodríguez-Rodríguez, D., Sciberras, M., Foster, N., \& Attrill, M. (2015). Status of management effort in 153 marine protected areas across the English Channel. Marine Pollution Bulletin, 94, 168-175.

Stephenson, R., Paul, S., Wiber, M., Angel, E., Benson, A., Charles, A., ... Sumaila, U. R. (2018). Evaluating and implementing social-ecological systems: A comprehensive approach to sustainable fisheries. Fish and Fisheries, 19(5), 853-873.

Sumaila, U. R., Lam, V., Miller, D., Teh, L., Watson, R., Zeller, D., ... Pauly, D. (2015). Winners and losers in a world where the high seas is closed to fishing. Scientific Reports, 5, 8481.

Swartz, W., Sala, E., Tracey, S., Watson, R., \& Pauly, D. (2010). The Spatial Expansion and Ecological Footprint of Fisheries (1950 to Present). PLOS ONE, 5(12), e15143.

Teh, L., Cheung, W., Christensen, V., \& Sumaila, U. (2017). Can we meet the Target? Status and future trends for fisheries sustainability. Current Opinion in Environmental Sustainability, 29, 118-130.

The World Bank. (2005). Hidden Harvest: The Global Contribution of Capture Fisheries (No. 66469GLB). Washington, DC: The World Bank.

Tuler, S., Webler, T., \& Polsky, C. (2013). A rapid impact and vulnerability assessment approach for commercial fisheries management. Ocean \& Coastal Management, 71, 131-140.

United Nations. (2017). Factsheet: People and Oceans. New York: United Nations.

Weeratunge, N., Béné, C., Siriwardane, R., Charles, A., Johnson, D., Allison, E., ... Badjeck, M.-C. (2014). Small-scale fisheries through the wellbeing lens. Fish and Fisheries, 15(2), 255-279.

World Bank, \& United Nations. (2017). The Potential of the Blue Economy: Increasing Long-Term Benefits of the Sustainable Use of Marine Resources for Small Island Developing States and Coastal Least Developed Countries. Washington, DC: World Bank. 